\title{
Paraskiewa-Petka Tyrnowska w rosyjskim wariancie służby - „monarchiczny” obraz świętości
}

\begin{abstract}
Kuczyńska Marzanna, Paraskiewa-Petka Tyrnowska $w$ rosyjskim wariancie stużby - „monarchiczny” obraz świętości (Parascheva of Tirnovo in the Russian Variant of Service - „Monarchical” Image of Holiness). „Poznańskie Studia Slawistyczne” 5. Poznań 2013. Adam Mickiewicz University Press, pp. 157-171. ISBN 978-83-232-2636-9. ISSN 2084-3011.

The article discusses the specific of sanctity of Parascheva of Tirnovo in the Russian Orthodox Church, an anchoress the most venerated by the Eastern Church. The pattern of holiness formed in the late nineteenth century is far richer and deeper than in other Slavic Orthodox churches. It is based on the Trinitarian, Christological, Marian themes, as well as on the strict hesychastic asceticism proper for hermits. The functions of the saint are also wider - she serves as a teacher, protector, defender, guardian of the state, the highest authorities (tsar) and the faithful - which is not typical for the sanctity of women, but rather for the holy hierarchs, bishops as pastors of the Church and the nation.
\end{abstract}

Keywords: Parascheva of Tirnovo; Orthodox holiness; Russian Orthodox Church; female sanctity; anchoress; Slavic/Russian hymnography

Paraskiewa-Petka Tyrnowska zajmuje wysokie miejsce wśród najbardziej czczonych świętych (Рогов 1982: 160), poświęcona jej literatura należy do najbogatszych i najbardziej zróżnicowanych. Przyczyniły się do tego peregrynacje relikwii po prawosławnym świecie, od miejsca pierwotnego pochówku w greckim Epiwacie, przez Bułgarię, Serbię, Turcję do rumuńskich Jass. Świadectwo zróżnicowania utworów dają polskie zbiory rękopisów cerkiewnosłowiańskich, w których odkryto ponad 40 różnych wersji tekstów ku jej czci (Kuczyńska 2003: 126-187). 


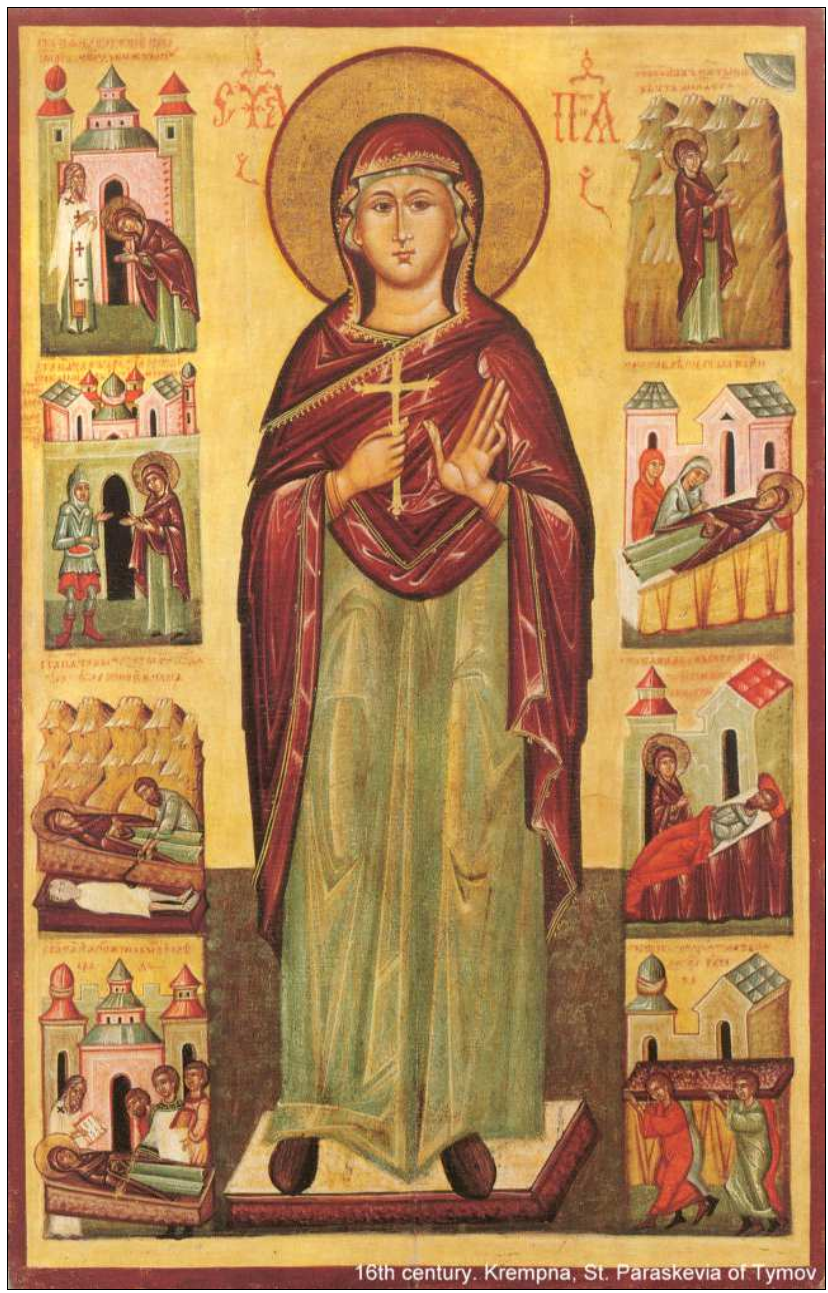

Ikona św. Paraskiewy-Petki Tyrnowskiej, XVI wiek, Krempna

Kult Petki przywędrował na Ruś z Półwyspu Bałkańskiego z falą emigrantów po tureckiej inwazji (Naumow 1996: 49-51; Чешмеджиев 2008). Łatwo się przyjął, ponieważ wierni identyfikowali imię anachoretki z męczennicą o tym samym imieniu. $\mathrm{Z}$ czasem w Cerkwi moskiewskiej kult 
męczennicy wchłonął kult ascetki (Суботин-Голубовић 2008; Чистякова 2011). Odwrotnie stało się na obszarze Rusi południowo-zachodniej, wchodzącej w skład państwa polsko-litewskiego, która budowała własną tożsamość religijną, nawiązując do tradycji bizantyńsko-słowiańskiej, by uniezależnić się od wpływów moskiewskich. Tu kult pustelnicy z Epiwatu zdominował męczeński kult Paraskiewy Rzymskiej.

Autorem jednego z bardziej rozpowszechnionych oficjów (służb) dedykowanych Petce, klasyfikowanego w nauce jako typ III, jest Grzegorz Cambłak (Kuczyńska 2003: 134). Oficjum obejmuje hymny zapożyczone z pierwotnego słowiańskiego nabożeństwa (z tzw. minei Dragana), przejęte ze służby serbskiej oraz z zachodnioruskich redakcji utworu typu $\mathrm{I}^{1}$. Omawiane tu oficjum stanowi wariant tekstu typu III. To obszerny utwór wzbogacony o sześć nowych sticher i chwałę na wieczerni oraz o nieznany wcześniej kanon na jutrzni. Niektóre hymny uległy tak ważnym przeróbkom, że można je uznać za specyficzne dla rosyjskiego tekstu, np. pierwszy sedalen jutrzni (ton 4$)^{2}$.

Imię Petki dla wschodniosłowiańskiego Kościoła utrwaliły Żywoty świętych metropolity rostowskiego Dymitra (Kijów 1689). Zbiór był wykorzystywany przez późniejszych hagiografów. Pisząc swoje dzieła, sięgał po niego na pewno arcybiskup czernihowski Filaret (Gumilow). Jedno z nich poświęcił świętym południowych Słowian (Czernihów 1865), zamieszczając żywot Paraskiewy.

Zainteresowanie tematem w latach 60. XIX w. przypisać można kilku przyczynom. Do ważniejszych należą idee panslawizmu i uroczyście obchodzone jubileusze: tysiąclecia powstania państwa (1862) oraz misji morawskiej (863), z czasem doszła 900. rocznica chrztu Rusi. Dużą rolę musiała odegrać także międzynarodowa polityka Rosji, która walczyła z Turcją, głosząc hasła wyzwolenia prawosławnych Słowian z islamskiej niewoli, jak i potrzeby lokalnej kijowskiej (,małoruskiej”) Cerkwi, bowiem tekst aktualizowany był zapewne z myślą o niej jako o ośrodku rozbudowanego kultu świętej.

\footnotetext{
${ }^{1}$ Cf. tabela - Kuczyńska 2003: 175-186.

${ }^{2}$ Pierwszy dostępny mi druk tekstu pochodzi z 1893 r.: Миниа, Октоврий, Киев 1893 : 123-131. Dziś służbę przedrukowuje się prawie bez zmian, cf. Минея, октябрь, ч. 2, Москва 1980: 379-397. Kwestia genezy przeróbki zasługuje na dalsze badania.
} 
Służbę przypuszczalnie przeredagowywano $\mathrm{w}$ drugiej połowie XIX wieku, unifikując model świętości jednej z największych patronek duchowych Rusi z aktualnie promowanymi wzorami religijnego posłannictwa. Praktyka korygowania rytualnych tekstów nie była obca rosyjskim liturgistom, kilkakrotnie modyfikowano na przykład oficjum ,,carskiego świętego", Dymitra Rostowskiego (1759, 1763, 1798, 1909). Lata 80. i 90. XIX stulecia to również ożywiony ruch na rzecz unifikacji liturgicznych ksiagg (Кравецкий, Плетнева 2001: 74-94). Ujednolicano głównie druki kijowskie i moskiewskie, niewykluczone, że pod wpływem tych tendencji decydowano się też na głębsze ingerencje tekstowe. Zmieniona służba ku czci Petki nosi charakterystyczne dla rosyjskiej obrzędowości cechy tematyczne i artystyczne (model obrazowania, stylistyka, duchowość). Przystosowana jest do życia społecznego Rosji, które nabrało wtedy niezwykłego tempa. Społeczeństwo kraju uległo znacznemu rozwarstwieniu, elity fascynowały się Zachodem, jego kultura, filozofią, liberalizmem światopoglądowym. Pociagały je koncepcje anarchistyczne. Lew Tołstoj głosił prywatną egzegezę Biblii, grupując wokół siebie zwolenników podobnych poglądów. Kościoły protestanckie organizowały coraz więcej własnych parafii (Kuczyńska 2011: 140). W tym układzie musiała odnaleźć się Cerkiew, sprowadzona od czasów Piotra I do roli jeszcze jednego urzędu państwowego. Dopiero ostatni car Mikołaj II legitymizował swe rządy sankcją duchowną. Nie zmienił formalnej pozycji Kościoła, Synod Cerkwi nadal mógł kontaktować się ze swoim zwierzchnikiem, carem, wyłącznie za pośrednictwem urzędnika świeckiego, nadprokuratora Synodu, ale poczynił szereg kroków, by przywrócić godność tradycyjnego błagoczestia. Kanonizowano coraz to nowych rodzimych świętych, poświadczając tym opiekę Bożą nad rosyjską ziemią.

Patronowała jej także Paraskiewa-Petka. Nigdy dane o historycznych losach pustelnicy nie były szczegółowe. Postać kreowano zgodnie z założeniami typu świętości. Na nowych terenach, na których rozwijano kult, zasadą stało stało się pozbawianie utworów o niej dawnych szczegółów geograficznych czy realiów kulturowych. Najbardziej skonkretyzowana tzw. tyrnowska wersja służby jest najsłabiej rozpowszechnionym utworem о świętej (Кожухаров 1971; 1974). Jednocześnie to na obszarze literatury ruskiej i rosyjskiej dokonało się ostateczne zeslawizowanie rodowodu Petki. Zasadniczo od wydania żywotów Dymitra i Filareta stale uważano ją 
za Słowiankę, Serbkę lub Bułgarkę. Stopniowo rósł także prestiż rodu świętej, z niewiele wpierw znaczacego, ale „pobożnego”, do wysokiego i możnego. Stranowiło to dopełnienie wzorca postaci, którego formowanie rozpoczął ostatni patriarcha bułgarski Eutymiusz, gdy w żywocie swego autorstwa nadawał jej funkcje strażniczki i obrończyni kraju, jego stolicy, a także patronki cara, dynastii i całego narodu (Eutymiusz 1986: 577-581; Lis 2004: 89-90; v. Демина 1994). Wywyższenie społeczne Paraskiewy w Rosji wpisywało się też w ogólniejszą tendencję ówczesnej hagiologii, która włączyła szlachetne pochodzenie do rejestru motywów stałych, zwłaszcza w literaturze ku czci świętych biskupów, umacniając prestiż duchowieństwa i autorytet instytucjonalnej Cerkwi.

Rosyjski wariant oficjum dedykowanego Petce podtrzymuje duch chrześcijańskiego uniwersalizmu. Figurę świętej kształtują obrazy biblijne, topika maryjna, chrystologiczna oraz anachorecki hezychazm. Dane biograficzne ograniczają się do greckiej Kalikratii, koło której mieszkała. Używane tu określenie „ojczyzna” (отечество) jest na tyle nieprecyzyjne, terminologicznie i kontekstowo, że odbiorca może utożsamiać ją z własną ojczyzną, np. z Rosją.

Paraskiewę opisano według wzoru prepodobnej, zarezerwowanego dla duchowości monastycznej, pustelników ascetów oraz mnichów ze wspólnot klasztornych. Wiadomo, że autor obrzędowy, zwłaszcza hymnograf, ma ograniczoną wolność twórcza, na Wschodzie dodatkowo implikowaną perspektywą wieczności - ziszczonej już świętości - nie prezentuje człowieka w jego walce o doskonałość, ale zamknięty model odpowiedniej realizacji życiowego powołania, którego finał następuje w niebie. Tak więc możliwości twórcy zredukowane są do swobody wyboru obrazów i formuł stosownych dla określonego typu świętości, który zdobi tylko lekki rys indywidualny. Żaden wszakże wybór, nawet najbardziej ogólny (np. z zakresu topiki biblijnej), nigdy nie jest przypadkowy, musi być motywowany kontekstem, przez który będzie odbierany i rozumiany jako aktualny, niosący ważne treści tu i teraz.

Dla konkretnego wizerunku świętego ważna jest uobecniona w tekście wizja świata, który zostaje zanegowany, postawiony w stan „oskarżenia”, by go usprawiedliwić działaniem Bożego wybrańca i zaakceptować w sakralnej formie. Świat z nabożeństwa ku czci Petki warunkuje aktualna historyczno-duchowa sytuacja Rosji, określana Koheletową ideą vanitas 
(Koh 1,2$)$ - to pełnoprawne civitas diaboli będące w stanie wojny z civitas dei. Odczucie dualistycznego napięcia wzmacnia czynna obecność $\mathrm{w}$ tej rzeczywistości diabła jako „,dostarczyciela ziemskich rozkoszy” i „zabójcy człowieka" ${ }^{3}$. Na destabilizację wskazują typowe biblijno-teologiczne symbole mroku, herezji, żywiołów (burza) ${ }^{4}$, nieszczęścia, cielesnych żądz, smrodu, rozpadu, odczucie braku bezpieczeństwa sygnalizowane przez potrzebę posiadania „przystani” lub oddania się pod opiekę. Zawsze oznaczają one naruszenie ustalonych reguł, brak fundamentu, niepokój i niebezpieczeństwo zagrażające istnieniu (cf. Hi 38,1; 8-11; Wj 19,3-6; 20, 1-17; Mt 14,24-33; Mk 4,35-41).

Człowieka tej przestrzeni kreuje miejsce. Bezwolnie poddaje się on wpływowi doczesności - diabelskiego świata, wypełnionego śmiertelnymi pułapkami, pokusą (cf. IX, 2). Tak ważną dla eklezjalnej wspólnoty prawosławia soborowość zabija indywidualizm, pragnienie osobistego szczęścia, w oficjum na cześć Petki sprowadzone do posiadania męża ${ }^{5}$. Moralność podporządkowana jest realizacji ziemskich celów, przyjemności, wygodzie. Przez kontekst biblijny całkowitą zależność od „ułudy” świata, nieumiejętność czy niemożność panowania nad nim trzeba połączyć z erozją postaw religijnych, ze słabością wiary, zwątpieniem (Mk 4,35-41). Rzeczywistość bez Boga wychowuje Paraskiewę przede wszystkim do odwagi bycia kimś innym, pozostania częścią Bożego świata, odrzuconego przez „państwo ziemskie”. Jej wybór i życiowe powołanie służy niwelowaniu zaistniałego rozdarcia między niebem a ziemią.

Rosyjski kult jest skorelowany z aktywnością polemiczno-wychowawczą Cerkwi i osadzony w micie początku. Sytuacja różnowierstwa, teologii prywatnych (Tołstoj), misji prawosławnych prowadzonych na obrzeżach kraju i poza jego granicami (np. na Syberii, na ewangelickiej Łotwie czy w Estonii) na pierwszym miejscu postawiła wykazanie, że depozyt Bożego objawienia spoczywa w Cerkwi prawosławnej i tylko ona dysponuje koniecznym instrumentarium do osiagnięcia życia wiecznego.

\footnotetext{
${ }^{3}$ Kanon 1, pieśń IX, tropar 2. Dalej będę podawać rzymską cyfrą numer pieśni, arabską troparu.

${ }^{4}$ Stichera po 50 psalmie na jutrzni, t. 8.

${ }^{5}$ Świadczy o tym przypisanie Petce pozostawania w związku narzeczeńskim. Cf. jutrznia, pierwszy sedalen, t. 4 .
} 
Gwarantem depozytu jest Paraskiewa, pełniąca na wzór starotestamentowych patriarchów funkcję pośrednika między Bogiem a ludem i przekaźnika Bożej prawdy. Autorzy najstarszych tekstów służb ku czci Petki widzieli $\mathrm{w}$ niej takiego właśnie przewodnika narodu, porównywali do Abrahama i Mojżesza, przez których był realizowany eschatologicznie orientowany plan wywyższenia i odkupienia człowieka (cf. Wj 6,2-4), ale zwykle jej wizerunki wypełniały model tylko częściowo. Późniejsze redakcje tekstu w ogóle pozbawiono tych personalizacji, najpewniej na skutek oderwania nabożeństwa od konkretnego miejsca, któremu niegdyś przydzielano określoną rolę $\mathrm{w}$ akcie zbawienia, oraz reinterpretacji sakralnego posłannictwa świętej. Omawiane oficjum przywraca jej wyobrażeniom osobowe funkcje $\mathrm{i}$ to $\mathrm{w}$ całościowym wymiarze - pośrednika wybranego do kontaktu z Bogiem i głoszenia Jego Słowa. Nigdzie wprawdzie nie nazywa się ascetki żadnym patriarchalnym imieniem, nie określa Mojżeszem czy choćby drugim Mojżeszem, lecz metaforyka sytuacyjna i czołowe atrybuty figury - tablice przymierza - jednoznacznie wskazują, że święta odgrywa rolę pełnoprawnego sygnatariusza przymierza i prawodawcy, dowodząc Bożego wybrania narodu i Cerkwi, nadprzyrodzonej genezy tej instytucji oraz cerkiewnych praw: „Na górę boskich cnót wspięłaś się, Paraskiewo, i w obłok spotkania wszedłszy, złączyłaś się z Bogiem, duchowe tablice błogosławionego Prawa przyjmując"6 (Wj 19; 20, 21; 24,12-18).

Dzięki wykorzystaniu mitu początku, Cerkiew i Rosja zyskują rangę niepodważalnej Bożej fundacji, świętej instytucji politycznej i eklezjalnej, dysponującej jedyną, bo Bożą, Prawdą i racją. Tu znalazł sobie miejsce doczesny odpowiednik ,państwa Bożego” z całokształtem plenipotencji władzy. Wszystko, co poza nimi, należy do civitas diaboli, jest odłączone, wykluczone z obietnic. Szansą dla tych, którzy odpadli, jest uznanie swego błędu i powrót do jedności. Nie może być wątpliwości, że chodzi o rosyjską Cerkiew i państwo, choć nie pada ani razu takie uszczegółowienie, typowe dla rodzimych rosyjskich kultów. W przypadku cudzoziemki poradzono sobie inaczej - Petka reprezentuje Rosję przez swą duchową obec-

6 „На гору божественных добродетелей востекла еси Параскево, и во облак видений приникши, сочеталася еси с Богом, разумныя скрижали приимши закона благодатнаго”, III, 3. (Tłumaczenia cytatów w artykule - M.K.). 
ność na liturgii, „w pieśni”7 ${ }^{\text {, }}$ i, jak już wiadomo, ma w miejscu odprawiania nabożeństwa swoją ,ojczyznę”.

Biblijne tło idei wybrania i przymierza oraz symbolika polemiczna dowodzą, że świadectwo Paraskiewy o obecności Boga w Cerkwi i Rosji oraz Jego Testamentu ma charakter pewny i ciagły, tzn. nieskażony, niezmienny w czasie, co zapisano pod metaforą rzeki z Syjonu, która gasi pragnienie wiernych: „Jak rzeka płyniesz z Syjonu, sławna Paraskiewo,

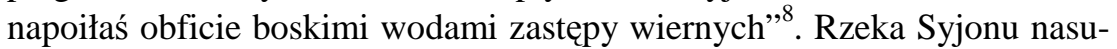
wa skojarzenia z psalmowymi rzekami Babilonu - Ps 137 (136),1 - nad którymi ukarany przez Boga za grzechy Izrael płakał nad swoim losem. Nowy rosyjski Izrael nad syjońską rzeką może być pewny swej bezgrzeszności i radować się z nieprzemijającej Bożej łaski.

Święta personifikuje program Cerkwi. Ze względu na liturgiczny charakter wschodniochrześcijańskiej kultury, państwa uważały swój ustrój za jeden święty porządek, przenikający wszystko. Społeczne aspekty działalności religijnej i świeckiej traktowano jako nieróżniące się od siebie. Duchowość silnie kształtowała tradycja monastyczna, szczególnie zreformowany w XIV wieku hezychazm z jego surową etyką ,pustyni”. To on stanowi fundament postaci Petki, tworząc wzór osobowo-moralny wiernego.

Asceza bałkańskiej pustelnicy w liturgicznej wizji rosyjskiej jest radykalna. Ogarnia ducha i ciało, umysł i serce, funkcjonuje nie tylko w ramach teologii wyrzeczenia, ale również cierpienia na wzór Chrystusa. Święta swym doświadczeniem ucieleśnia Najwyższego, równając swoje imię z Jego imieniem („,господоименита”, VII, 1). Brak tu miejsca na kompromisy ze światem - cały plan wypełnia Bóg jako suwerenny, rzeczywisty Stwórca i Pan świata. Jeżeli cokolwiek usiłuje przesłonić Jego postać, jest zwalczane dyscypliną psychiczną i fizyczną. Rejestr ćwiczeń Petki wylicza post, wstrzemięźliwość, czuwanie, pokłony, modlitwę, wierność, pobożny obyczaj, czystość, pokorę, samodyscyplinę, samopoświęcenie, stałość, miłość Boga i bliźniego. Wyczerpujące ćwiczenia w wypadkach koniecznych ${ }^{9}$ posuwane są do skrajności: post przechodzi

\footnotetext{
${ }^{7}$ Světilen.

8 „Яко река устремися от Сиона, славная Параскево, напоила еси зело божественными струями верных сонмы”; Ps 96 (95), 1-13, I, 2.

${ }^{9} \mathrm{Na}$ przykład młodzieńcze problemy z pożądliwością cielesną.
} 
w głodówkę (IV, 2), wstrzemięźliwość prowadzi do pełnego uniżenia (leżenie na ziemi - znak nicości), pokorę cechuje doskonałość, modlitwę gorliwość $^{10}$, pragnienie naśladowania Pana - niezmienność (VII, 1). Wyraz należytej oceny doczesnej radości daje informacja o rezygnacji świętej ze szczęścia małżeńskiego, o wyrzeczeniu się ziemskiego (przemijającego) męża na rzecz niebieskiego Oblubieńca ${ }^{11}$. To ciekawy wypadek aktualizacji i indywidualizacji kultu, żaden inny tekst o Petce nie uwzględnia go ${ }^{12}$. Motyw porzucenia rodziny dotyczy rodziców, rodzinnego domu ${ }^{13}$, tu może być próbą rozbudzenia i pogłębienia religijnych uczuć kobiet, dorastającej młodzieży albo przypomnienia wiernym, że stan małżeński według kryteriów sakralnych znajduje się na końcu drabiny zbawienia.

Petka dostarcza ponadto wzoru autokontroli i skruchy dzięki darowi łez, który umożliwia rozpoznanie głębi duchowego upadku i szukania odpowiednich środków zaradczych ${ }^{14}$. Linie doloryczne jej świętości - teoria vanitas, świat jako $\operatorname{sen}^{15}$, teologia cierpienia - znajdują dopełnienie, ale i nadzieję w idei nieprzemijającej nagrody w niebie za wszystkie ziemskie trudy, które w doczesnym wymiarze nie zostały wynagrodzone. Chrześcijańską doskonałość świętej wyraża maryjny obraz całkowitego wypełnienia jej wnętrza przez Boga tak, że nie istnieje już żadna przestrzeń, którą mógłby zająć grzech.

Przełamanie w sobie samej dysonansu między sacrum a profanum, wewnętrzna harmonia predestynuje Petkę do wkroczenia do świata. Zakres jej sakralnych funkcji jest wyjątkowo szeroki, określa je głównie mariologia, związana z koncepcją Bogurodzicy - Matki Kościoła, oferując wa-

${ }^{10}$ To znaczy odpowiednia postawa modlitewna, koncentracja na rozmowie z Bogiem, cf. wielka wieczernia (dalej: WW), stichery na „stichovně”, t. 4.

11 „Oblubieńca umiłowawszy, Stwórcę i Boga, oblubieńca ziemskiego opuściłaś, czcigodna Paraskiewo, i z radością znosiłaś ćwiczenia postu” („Жениха возлюбивши творца и бога, жениха же тленнаго оставила еси, честная Параскево, и, радующися, претерпела еси постныя подвиги”). Jutrznia, pierwszy sedalen, t. 4.

${ }^{12}$ Wzbogacanie życiorysów świętych zdarzało się często. W jednej z kopii podano, że Petka porzuciła klasztor (Biblioteka Metropolitalnego Seminarium Duchownego w Lublinie, MSD 552).

${ }^{13}$ Wpływ mogła też mieć hymnografia Paraskiewy męczennicy (28 X) lub służby ogólnej męczennicy.

${ }^{14}$ WW, stichera 3 na „Do Ciebie wołam, Panie”.

${ }^{15}$ Idee szczególnie rozwinięte w wieczornych sticherach na ,stichovně”. 
chlarz możliwości niedostępnych inaczej dla pozainstytucjonalnego (pozahierarchicznego) życiowego powołania, jakie wyznaczono kobietom.

$\mathrm{Na}$ czele obowiązków stoi misja nauczycielska. O wadze nauczania świadczy sposób jego literackiego przedstawienia, motyw ten przywoływany jest często i uobecniany za pomocą metafor ${ }^{16}$, jak również bardziej realistycznie, wręcz klasycznie - przy użyciu słowa ${ }^{17}$, wzorem duszpasterzy, kaznodziejów. Takie „awangardowe” podejście do żeńskiego kultu, łamiące nakaz milczenia kobiet w Kościele (1 Kor 14,34) mogło być tłumaczone koniecznością wsparcia wewnętrznej prawosławnej akcji misyjnej, organizowanej przez Cerkiew na terenach zróżnicowanych wyznaniowo (np. na pograniczu rosyjsko-austriackim) lub wśród innowierców ${ }^{18}$, aby jedną wspólną religią, wspólnymi wartościami integrować społeczeństwo kraju.

Oddziaływanie kultu Petki ukierunkowuje się na duchowe poruszenie człowieka, wzbudzenie religijnych potrzeb i uczuć z jednej strony, z drugiej na umacnianie pobożności, kształtowanie niewzruszonych postaw chrześcijańskich, silnych charakterów, odpornych na pokusy i gotowych na wyzwania. Ma dostarczyć dowodów, że wyznawana wiara nie jest powierzchowna, tymczasowa albo pozorna, że wierny nie cofa się pod naciskiem wroga, lecz na odwrót, swoim zachowaniem przyciaga, nawraca na prawosławie.

Świętość tej, która dostapiła łaski spotkania z Bogiem i poznania Go, utrzymana w ścisłej prawosławnej ortodoksji, orientowana trynitarnie i maryjnie ${ }^{19}$ pozwala rozciągnąć jej oświatowe zadania na walkę z innowierstwem. Uczynić z niej pełnoprawną strażniczkę i obrończynię depozytu Cerkwi - wiedzy, wiary, obyczaju - wroga „herezji” (V, 1). Paraskiewa jako „oświecicielka” - rozprasza ciemności herezji ${ }^{20}$, mroczne heretyckie

${ }^{16} \mathrm{Na}$ przykład rozganianie mroku światłem nauki, karmienie ludzi mądrością pobożnego obyczaju (III, 1), wylewanie mirry aromatycznych i „mądrych” nauk, wydzielanie miłej woni dobrego obyczaju (VIII, 3).

17 „Rzekami słów miodopłynnych, Paraskiewo, napełniasz ludzkie dusze” („Реки твоих словес медоточных, Параскево, человеком души [...] исполняеши”). VII, 3.

${ }^{18}$ Akcję kierowano m.in. do Żydów czy emigrantów z innych krajów (Нагорна 2003: 347-352).

${ }^{19}$ Paraskiewę dodatkowo przedstawia się jako czcicielkę Bogurodzicy.

${ }^{20}$ WW, stichera 1 na „Do Ciebie wołam, Panie”. 
ciemności trzebi, odgania heretyckie zło (III, 2). Idea dualizmu świata przekształca figurę Petki w żołnierza Chrystusowego uzbrojonego w broń ascezy. Odbija ona wodza niebieskich wojsk, Archanioła Michała, w walce z upadłym aniołem, gdy „strąca wyniosłą pychę z wysokości na ziemię”. Uosabia zarazem Chrystusowy miecz, który oddziela dobro od zła (cf. Mt 10,34 i n.; Ef 6,10-17): „Gdy zajaśniałaś, sławna, życia poprawą, objawiłaś się naostrzona jak Chrystusowy miecz i siekłaś pułapki demona, umacniana Bożym duchem" $"$.

„Władza miecza” na przełomie XIX i XX stulecia zasadniczo znajdowała się wśród toposów rezerwowanych dla hierarchicznej, chrystologicznej świętości biskupów, za pomocą której wspierano imperialną ideologię państwa (w ramach zasady cerkiewnej symfonii). Niekiedy, według teologii politycznej, uobecniała świętość „carską” - majestat monarchy, dynastii, imperium - jako czynnik konieczny do realizacji zbawczej rosyjskiej misji w świecie, ustanowionej przez Boga do obrony wiary, Kościoła i wiernych. Realizacja celu wymagała posiadania skutecznych narzędzi walki, w tym również wojska będącego zbrojnym ramieniem cara, państwa i Kościoła, aby móc czynnie bronić wiary bądź szerzyć ją wśród pogan (albo „niepokornych heretyków”) w formie wypraw krucjatowych. Akceptacja prawa Paraskiewy do udziału we władzy miecza włącza ją do grona wybranych „państwowych” świętych, autoryzujących boskość władzy, i może być uznana za legitymizację wykorzystania radykalnych rozwiązań w starciu z innowiercami. Motyw wpisuje się też w obraz Bogurodzicy Hetmanki, jednego z głównych patriotycznych symboli Rosji, który widniał na wojennych sztandarach, tym bardziej że kończący tę sekwencję strof ku czci Petki hymn maryjny gloryfikuje właśnie Matkę Bożą Hetmankę $e^{22}$ - opiekunkę armii i jej wodza, cara. Dawna Ruś, a później Rosja czciły ten typ świętości Bogurodzicy pod kilkoma wizerunkami: Matki

21 „Облиставши, славная, жития исправлении, обощрена явилася еси яко Христов мечь, ссецающи демонская ухищрения божественным духом укрепляема”, IV, 3 .

${ }^{22}$ Tekst pieśni, uzupełniony w nawiasach kwadratowych o wersję przedrewolucyjną z 1893: „Chroniąc ludzi wiernych [cara wiernego] w walce, wojsku [Imperatorowi] naszemu daj zwycięstwa, Bogorodzicielko, i broń od wszelkiego ataku wrogów” („Поборствующи людем верным [царем] во бранех, воинству [Императору] нашему на сопротивныя даждь победы, Богородительнице, покрывающи от всякаго навета врагов)”. 
Bożej Włodzimierskiej, Kazańskiej, Teodorowskiej ${ }^{23}$. Ostatni uchodził za ikonę patronacką domu Romanowów i ich państwa, według tradycji miał decydujące znaczenie dla objęcia tronu po latach „smuty” przez Michała Romanowa (3 marca 1613 roku) i „wziął” na prośbę matki pod swą opiekę młodego cara. Sam wizerunek ikonograficzny nie nosił charakteru „Królowej Nieba i Ziemi”, która patronowała Bizancjum, ta w Rosji miała się objawić dopiero po detronizacji Mikołaja II (2 marca 1917 roku $)^{24}$, był w typie obrazu symbolizującego opiekę nad „,domem Bogurodzicy”, Rosją. Pełnomocnictwa królowej wyobrażono przez dodanie do zdobiącego ikonę okładu królewskiej korony z krzyżem.

Walka o ortodoksję dotyczy również prawosławnej teologii wyrazu, dla której widziano zagrożenie $w$ wyobrażeniach plastycznych innych religii, w sekularyzacji życia, a być może także w formie cerkiewnej sztuki, która w ciągu XVII i XVIII wieku zaczęła we wschodniej Słowiańszczyźnie ulegać istotnym przemianom, wzorując się na malarstwie religijnym Zachodu. W rosyjskiej służbie Paraskiewa jawi się jako zdeklarowany przeciwnik wszelkich nieprawosławnych religijnych artefaktów, które można traktować również jako sprzeciw wobec artystycznego nowatorstwa - negacji koncepcji sztuki opartej na dogmacie wcielenia, nieposiadającej autoryzacji prawa Bożego ani świętej Tradycji. Tak wyobrażona Petka kategorycznie potępia „,obcą” ikonografię, widząc w niej wizerunki demonów zamiast świętych ${ }^{25}$. Domaga się respektowania prawosławnych wzorów. Jako obrończyni obrazów otrzymuje charakterystyczne dla rosyjskiej duchowości rysy szalonej w Chrystusie: „Namalowany czcigodny i święty obraz godnie całujesz, bezbożnych zaś malunki niszczysz, a ich się ikony.

${ }^{23}$ Od imienia św. Teodora $(+319,2$ II), patrona żołnierzy, z nim wiązano pojawienie

${ }^{24}$ Matka Boża Królowa z Kołomienskoje (dziś obszar Moskwy) ma na głowie koronę, w ręku regalia - kulę ziemską (symbol państwa) i berło. Okrywa ją purpurowy płaszcz. Jezus składa dłonie do błogosławieństwa, z góry błogosławi państwu Bóg Ojciec. Obraz wyraża przejęcie przez Bogurodzicę władzy od ustępującego cara i zwiastuje oddanie jej, gdy kraj ulegnie odnowie. Dla monarchistów to wizja restytucji monarchii (Фомин 2007).

${ }^{25}$ „Po prawie Ojca, prawo ojców [tj. przodków - M.K.], błogosławiona, prawdziwie zachowując, oblicza demonów opluwałaś, a czcigodnie całowałaś wyobrażenie Pana, który przybył na ziemię, rodząc się z Dziewicy Maryi” („По законе Отчи, закон отеческий, всеблаженная, истинно носящи, демонская лица поплевала еси, Господне воображение благочестно лобызающи, еже приим в мире явившася от Девы Отроковицы”), VIII, 1. 
obmierzłe Bogu i bezbożne nakazy opluwasz, głosząc cześć i pokłonienie obrazowi Chrystusa",26.

Pełni wreszcie Petka funkcje opiekuńcze wobec wiernych, odzwierciedlając obrazy Matki Boskiej Przewodniczki (Hodegetrii) i Opiekunki (Pokrow) - jest przewodniczką błądzących, oparciem chwiejnych, drogowskazem zbaczających z kursu, opiekunką nieszczęśliwych, cichą przystanią zaniepokojonych ${ }^{27}$. Nie traci przy tym właściwych sobie cech wzorca kobiet, panien, mniszek (V, 2).

Duchowość Paraskiewy-Petki Tyrnowskiej w rosyjskiej przeróbce odtwarza dokonania nie tylko największych herosów pustyni, ale przez powierzoną sobie sferę działania odwzorowuje funkcje największych rosyjskich świętych przełomu XIX i XX wieku, przede wszystkim powołanych do zarządzania Kościołem biskupów, którzy zmagali się z rozpadem tradycyjnego społeczeństwa i zanikiem systemu wartości określanych przez ideał Świętej Rusi. Świętość Petki ma charakter wyjątkowo dydaktyczny, katechetyczny, nastawiony na działania misyjne (głównie misji wewnętrznej) o wymiarze państwowym, eklezjalnym, społecznym. Bez rezygnacji z hezychastycznego rysu, zakładającego izolację od świata, Paraskiewa otrzymuje i pełni ważkie funkcje publiczne - religio-, cerkiewno- i państwotwórcze, podbudowując oficjalną ideologię państwową, według której utożsamiano cesarstwo rosyjskie z Kościołem, a cara z Boskim posłannictwem na ziemi.

Ten kompleksowy wzorzec świętości czyni z Paraskiewy fundament (kolumnę) i podporę rosyjskiego prawosławia, normę (kanon) Cerkwi, mur przez nikogo niezwyciężony. Najlepiej świadczy o tym typowa dla rosyjskiej hymnografii scena deesis, rozbudowana do tzw. wielkiego deesis, w której efektywność patronatu Petki nad Rosją poświadcza obecność i modlitwa całego szeregu wybranych Pańskich, proszących za rosyjski Kościół wraz z nią - proroków, apostołów, męczenników, patriarchów (IX, 3).

26 „Написанный всечестный и святый образ любезно лобызаеши, безбожных же писания потребляеши, и тех богомерзская и безбожная повеления поплеваеши, и возвещаеши честь и поклонение образа Христова”, VI, 3.

27 Stichera po 50 psalmie, t. 8; V, 3: „Objawiłaś się (...) błądzących przewodniczką, drogowskazem zbaczających z kursu, chwiejnych umocnieniem i murem niewzruszonym" (,Явилася еси [...] заблуждших путеводительница, влающихся правительница, и колеблющихся в лютых твердость, и стена нерушима"). 
Tym samym rosyjskie dodatki hymniczne w służbie adaptują świętość bałkańskiej pustelnicy do miejscowych potrzeb społecznych, duchowych oraz kanonów estetyczno-semantycznych. Dzięki nim nabiera ona nieznanej na Bałkanach ani na obszarze prawosławia kijowskiego (trudno byłoby znaleźć jej żeński odpowiednik także w rosyjskiej Cerkwi) głębi i hierarchicznej funkcjonalności, dzięki czemu skuteczniej realizuje zadania defensywno-ofensywne stawiane przed rosyjską wspólnotą religijną.

\section{Literatura}

Чешмеджиев Д., 2008, Митрополит Киприан и култовете на българските светци, „Studi Slavistici” V, s. 15-30.

Чистякова М.В., 2011, Псковская проложная редакция жития великомучениць Параскевы Иконийской, w: Dziedzictwo kulturowe Wielkiego Księstwa Litewskiego. W 440. rocznice Unii Lubelskiej, red. S. Kawalou, M. Kojder, Lublin, s. $13-24$.

Демина Е., 1994, Новоболгарская версия „Жития Петки Тырновской” Патриарха Евфимия в трудах российских филологов ХІХ в., „Търновска книжовна школа" 5, Велико Търново, s. 259-272.

Eutymiusz, 1986, Żywot Paraskiewy, w: Стара българска литература. Житиеписни творби, t. 4, przekł., red. i kom. К. Иванова, София, s. 577-581.

Фомин С.В., 2007, Царица Небесная. Державная правительница Земли Русской, Москва.

Кожухаров С., 1971, Неизвестно произведение на старобългарската поезия, „Старобългарска литература” ks. 1, София, s. 292-301.

Кожухаров С., 1974, Търновската книжовна школа и развитието на химничната поезия в старата българска литература, w: Търновска книжовна школа 1371-1971, red. П. Русев, Г. Данчев, Е. Сарафова, София, s. 302-309.

Кравецкий А.Г., Плетнева А.А., 2001, История церкковнославянского языка в России (конеи XIX-XX в.), Москва, s. 74-94.

Kuczyńska M., 2003, Potudniowostowiańska poezja liturgiczna $w$ zbiorach bibliotek polskich, Szczecin.

Kuczyńska M., 2011, Z Zachodu na Wschód. Obywatele Rzeczypospolitej na ołtarzach Cerkwi rosyjskiej, Kraków.

Lis I., 2004, Święci w kulturze duchowej i ideologii Stowian prawosławnych $w$ średniowieczu (do $X V$ w.), Kraków. 
Минева Е., 2005, Пет химнографски творби за св. Петка Търновска, София.

Нагорна Т., 2003, Місіонерськи з'їизди як координуючі органи діяльності православних місій в Україні (кін. ХІХ - поч. ХХ ст.), w: Історія релігій в Украӥні, ks. 1, red. В. Гаюк, Львів, s. 347-352.

Naumow A., 1996, Wiara i historia. Z dziejów literatury cerkiewnostowiańskiej na ziemiach polsko-litewskich, „Krakowsko-wileńskie studia slawistyczne” t. 1, Kraków.

Рогов А.И., 1982, Петка Тырновская в восточнославянской письменности и исскустве, w: Русско-балканские культурные связи в эпоху средневековья, София, s. 160-181.

Станкова Р., 2012, Култ и химнография. Служби за местни южнославянски и балкански светции в ръкописи от XIII-XV в., София, s. 137-149.

Stradomski J., 1999, Święta Paraskiewa (Petka) w literaturze, kulturze i duchowości Stowian potudniowych $i$ wschodnich, w: Święci w kulturze i duchowości dawnej i wspótczesnej Europy, red. W. Stępniak-Minczewa, Z.J. Kijas, Kraków, s. 83-94.

Суботин-Голубовић Т., 2008, Петка Преподобна - Петка Мученица, „Зборник радова Византолошког института" XLV, s. 177-190. 
